Dobrivoje Vulićević poručnik, dipl. inž. Vojna akademija - Odsek logistike,

Žarko Aćimović, dipl. inž.

ASW Inženjering d.o.o. Beograd

mr Dušan Bobić, pukovnik, dipl. inž.

Vojna akademija - Odsek logistike,
Beograd

Rezime:

Izrada rasporeda časova u visokoškolskim ustanovama vrlo je složen i obiman proces. $U$ radu je predstavljen informacioni sistem za automatizaciju planiranja rasporeda časova. Softver omogućava unos $i$ čuvanje svih relevantnih podataka o predmetima (nastavnim planovima i programima), nastavnicima (pripadajućim katedrama), specijalnostima, nastavnim grupama, brojnim stanjem grupa, prostorijama (učionice, laboratorije) i brzu izradu zahtevanih izveštaja rasporeda časova (klasičan, po danima, po predmetima, itd.). Softversko rešenje obuhvata bazu podataka projektovanu na platformi Microsoft SQL Server 2000 i korisnički interfejs projektovan alatom Microsoft Access 2000.

Ključne reči: raspored časova, informacioni sistem, softver.

\title{
SOFTWARE SOLUTION FOR PLANNING TIMETABLES IN THE HIGH
}

EDUCATIONAL INSTITUTIONS

Summary:

Planning timetables in high educational institutions is very complex and tiresome process. This paper presents information system for automatization of planning timetables. Software provides input and saving of all relevant data concerning subjects, teachers, specialties, student groups, facilities (classrooms, laboratories) and quick presentation of different report types about timetables. The software solution involves database designed on Microsoft SQL Server 2000 platform and user interface coded using Microsoft Access 2000.

Key words: timetable, information system, software.

\section{Uvod}

Jedan od bitnih zadataka koje realizuje nastavno odeljenje visokoškolske ustanove je semestralno planiranje, izrada i praćenje realizacije rasporeda časova. Organizaciona struktura svakog fakulteta veoma je složena. Struktura vojne visokoškolske ustanove, kao što je Odsek logistike Vojne akademije, predstavlja skup fakulteta različitih usmerenja, kao što su: mašinsko usmerenje, elektro usmerenje, informatika, ekonomske nauke, saobraćaj i druga. U takvim ustanovama školuje se veliki broj smerova i specijalnosti. Školovanje traje pet godina, a da bi student uspešno završio školovanje, treba da položi prosečno 52 ispita. Semestralno, za jednu nastavnu grupu, planira se od sedam do devet predmeta. Nastavu realizuje, pored stalnih nastavnika, i veliki broj spoljnih saradnika sa Beogradskog univerziteta, iz Ministarstva odbrane i jedinica Vojske Srbije i Crne Gore.

Pojedine predmete sluša više nastavnih grupa istovremeno, što utiče na izbor odgovarajuće prostorije potrebnog kapaciteta. Prema Nastavnom planu i programu 
ukupan broj predmeta premašuje 500 (za ukupno vreme školovanja), tako da se za jedan semestar planira u proseku više od 100 različitih predmeta. Raspored časova obuhvata termine realizacije predmeta, nastavnu grupu (smer, godinu školovanja odnosno klasu i specijalnost), predmet, nastavnika, prostoriju za realizaciju nastave i brojno stanje slušalaca.

Nastavni proces organizuje se za više od 20 specijalnosti, razvrstanih u više od 50 nastavnih grupa. To znači da se istovremeno realizuje više od 20 nastavnih planova i programa. Maksimalno se teži grupisanju nastave srodnih specijalnosti na realizaciji određenog predmeta. To znači da je u jednom semestru potrebno planirati oko 50 različitih rasporeda.

Jasno je da je planiranje i izrada rasporeda časova veoma složen i dugotrajan proces. Uočeno je da je jedan od glavnih faktora koji negativno utiču na vremenski aspekt realizacije planiranja i izrade rasporeda časova nepostojanje kvalitetnog rešenja za informatičku podršku tom procesu. Dosadašnje rešenje zasnivalo se na izradi rasporeda časova popunjavanjem obrazaca izrađenih u alatu Microsoft Word. Ovakav pristup imao je niz nedostataka:

- izuzetno teško generisanje odgovarajućih izveštaja,

- veliko angažovanje učesnika u realizaciji ovog zadatka,

- nemogućnost automatske validacije unetih podataka,

- velika mogućnost nastanka greške.

U radu je predstavljeno softversko rešenje za planiranje i izradu rasporeda časova koje omogućuje, nakon unosa relevantnih podataka, lako i brzo kreiranje izveštaja prema korisnicima, praćenje re- alizacije nastave, ažuriranje podataka i automatsku proveru podataka otkrivanjem eventualnih grešaka nastalih u planiranju.

\section{Analiza problema}

Pored navedenih problema $\mathrm{u}$ izradi rasporeda časova značajnu poteškoću predstavljale su i naknadne izmene rasporeda, kao posledica dodatnih zahteva učesnika u realizaciji nastave. Dosadašnji način rada zahtevao je prekrajanje i ponovno usklađivanje termina (vodeći računa da ne dođe do preklapanja, odnosno istovremeno planiranja dva predmeta u istoj prostoriji ili istovremeno planiranje jednog nastavnika u različitim grupama, itd.), kao i višednevni rad referenata u nastavnom odeljenju. Rešenje problema planiranja rasporeda časova nije nađeno ni u okviru Beogradskog univerziteta. Pošto se svi navedeni problemi nisu mogli uspešno rešiti modifikovanjem postojećeg rešenja, odlučeno je da se pristupi projektovanju informacionog sistema, koji će omogućiti izradu rasporeda časova angažovanjem jednog referenta, tako što će se automatizovati sledeći procesi:

- unošenje podataka o predmetima po smerovima i specijalnostima (NPP), uz maksimalno smanjenje mogućnosti nastanka greške kao posledice ljudskog faktora;

- unošenje podataka o smerovima, nastavnim grupama, specijalnostima, brojnom stanju, prostorijama i $\mathrm{dr}$.;

- unošenje podataka u raspored časova o predmetima (predavanja, vežbe), nastavnicima i učionicama po danima realizacije; 
- izrada, ažuriranje i štampanje svih potrebnih izveštaja rasporeda (za smer, nastavnu grupu, po danima, itd.);

- kreiranje polazne osnove rasporeda za naredni semestar (zimski ili letnji), na osnovu podataka iz prethodnog;

- automatska provera ispravnosti unetih podataka (o preklapanju prostorija, nastavnika i dr.).

Proces planiranja i izrade rasporeda časova realizuje se kroz nekoliko faza. Prvu fazu čini usaglašavanje termina nastave zajedničkih predmeta za više različitih nastavnih grupa. Drugu fazu predstavlja koordinacija nastave za predmete koje sluša samo jedna nastavna grupa. U trećoj fazi vrši se objedinjavanje svih predmeta za predstojeći semestar i vrši provera podataka. Izrađeni raspored časova distribuira se svim nastavnim grupama čiji studenti slušaju nastavu u predstojećem semestru i svim organizacionim jedinicama čiji nastavnici treba da realizuju nastavu.

Informacioni sistem treba da radi $u$ mrežnom okruženju i da podržava više različitih nivoa prava pristupa podacima.

Imajući u vidu i buduće korisnike informacionog sistema, definisana su četiri nivoa prava pristupa. Prvi nivo pristupa predstavlja administrator sistema koji ima neograničen pristup svim podacima uz mogućnost unosa, pregledanja, ažuriranja i brisanja. Drugi nivo predstavljaju lica iz organa za planiranje koja učestvuju u izradi rasporeda časova. Oni mogu da unose izmene, ažuriraju i pregledaju podatke, kao i da izrađuju sve potrebne izveštaje. Brisanje podataka dozvoljeno je uz posebnu šifru. Treći nivo su rukovodioci nastavnih grupa koji imaju ista prava kao i lica iz organa za planiranje, ali samo nad podacima vezanim za svoju nastavnu grupu. Četvrti nivo čine nastavnici i studenti koji imaju pravo pristupa isključivo radi uvida u planirane termine nastave, bez mogućnosti bilo kakvih izmena.

Nakon definisanja prava pristupa pristupilo se izradi modela podataka. U ovoj fazi trebalo je obratiti naročitu pažnju na univerzalnost modela i mogućnosti njegovog proširenja. Informacioni sistem za planiranje rasporeda časova automatizuje samo deo poslova nastavnog organa.

\section{Model podataka i predložena arhitektura sistema}

Za izradu modela podataka korišćen je CASE alat ERwin zbog svoje rasprostranjenosti i mogućnosti automatskog generisanja baze podataka iz projektovanog modela. Logički model podataka prikazan je na slici 1 .

Model podataka izrađen je tako da omogućava maksimalnu efikasnost pri generisanju svih potrebnih izveštaja vezanih za raspored časova. Naročito je trebalo obratiti pažnju na univerzalnost modela, kako bi se informacioni sistem koji se razvija mogao lako primeniti u različitim obrazovnim ustanovama koje imaju potrebu za rasporedom časova. U prilog tome govori i činjenica da je uz minimalne izmene generisanih izveštaja i nijednu izmenu modela, aplikacija prilagođena Srednjoj zanatskoj školi u Beogradu, koja, poput Odseka logistike Vojne akademije, ima veći broj obrazovnih profila. 


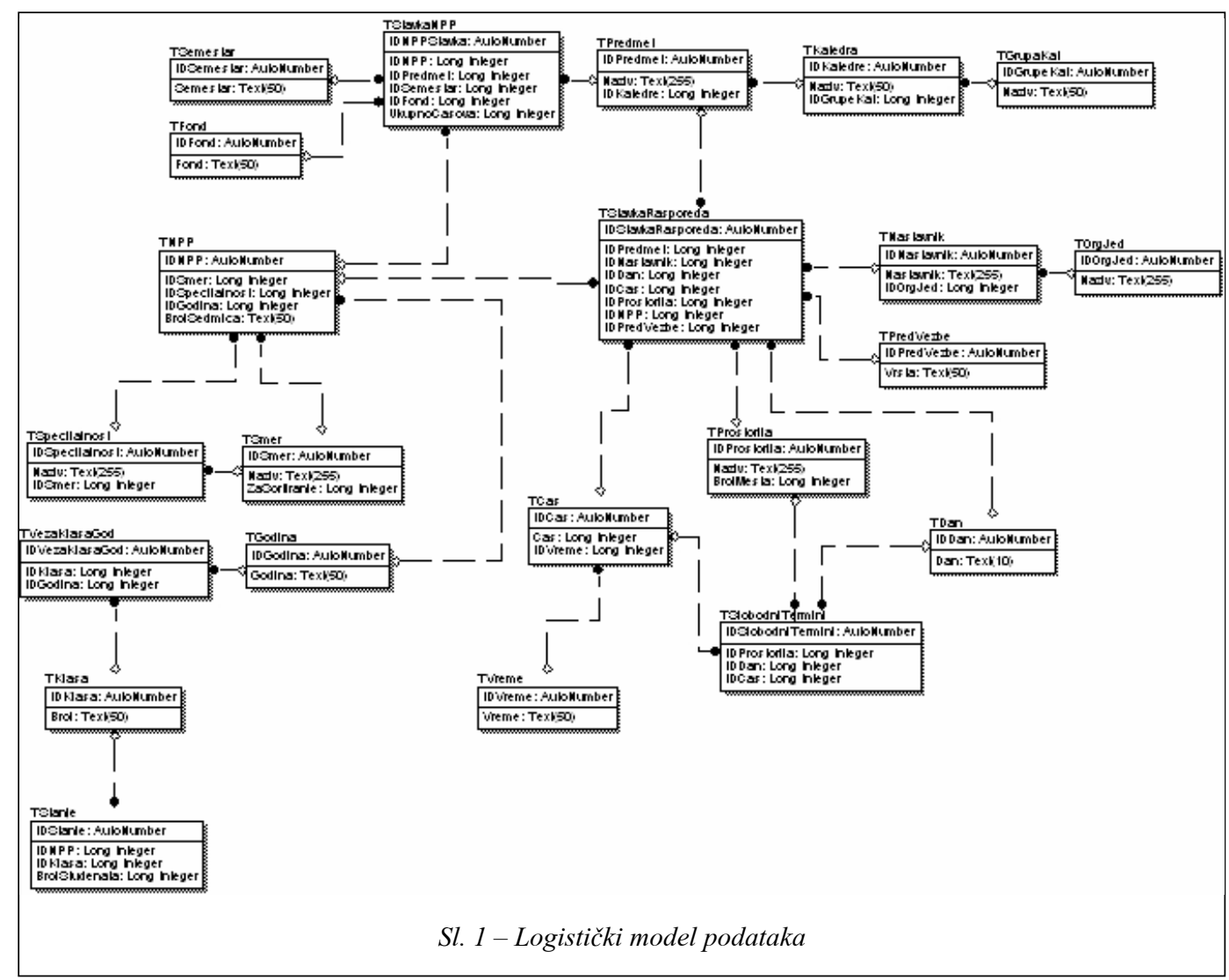

Ključna tabela u modelu je tabela StavkaRasporeda koja sadrži sve relevantne podatke bitne za jedan čas (predmet koji se sluša, obrazovni profil koji ga sluša, nastavnik koji predaje, termin i prostorija). Svi ovi atributi se kao strani ključevi prenose iz ostalih tabela, takozvanih šifarnika. Na ovaj način obezbeđeno je da se generisanje jednog termina za predavanje vrši samo izborom željenih podataka iz liste ponuđenih, čime je maksimalno smanjena mogućnost nastanka greške usled pogrešnog unosa.

Problem koji se javio pri izradi modela podataka jesu višestruke međusobne zavisnosti koje postoje između nastavnih grupa različitih smerova, godina školova- nja i specijalnosti. Nakon detaljne analize zahteva budućih korisnika informacionog sistema i tendencija razvoja školstva, usvojena je organizacija modela podataka prikazana na slici 1 . Pojedini smerovi ne moraju imati na školovanju sve postojeće specijalnosti, a neki, u zavisnosti od svoje organizacijsko-formacijske strukture, ne moraju imati ni čitavu godinu školovanja (klasu studenata).

Tabele Katedra i OrgJed uvedene su da bi se omogućilo grupisanje nastavnika koji izvode nastavu u dve grupe:

- nastavnici iz katedri visokoškolske ustanove koja je nosilac realizacije Nastavnog plana i programa, 
- spoljni saradnici koji se angažuju preko drugih visokoškolskih ustanova (fakulteta Beogradskog univerziteta, Ministarstva odbrane ili iz jedinica Vojske Srbije i Crne Gore).

$\mathrm{Na}$ ovaj način omogućeno je lako i selektivno generisanje izveštaja o nastavnim obavezama u predstojećem semestru i njihovo blagovremeno dostavljanje svakoj pojedinačnoj organizacionoj jedinici čiji nastavnici realizuju nastavu.

$\mathrm{Za}$ implementaciju informatičkog rešenja izabrana je troslojna arhitektura sistema, prikazana na slici 2 .

Nakon izrade modela podataka pristupilo se generisanju baze podataka u kojoj će se pohranjivati svi budući podaci. Kao sistem za upravljanje bazom podataka (server baze podataka) izabran je Microsoft SQL Server 2000. Razlozi za ovakav izbor bili su

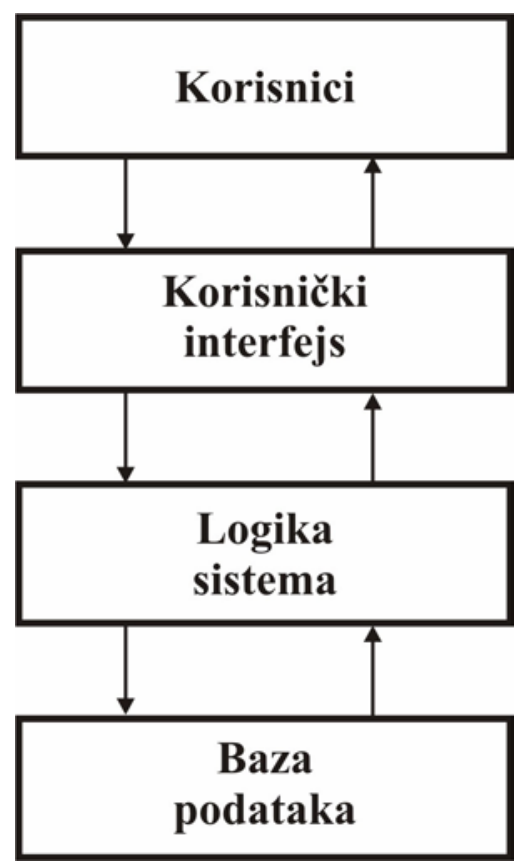

Sl. 2 - Troslojna arhitektura sistema višestruki. SQL Server je alat koji je najrasprostranjeniji u Vojsci Srbije i Crne Gore, a izučava se i u okviru kursa na redovnim studijama na smeru službe informatike. S obzirom na to da se jedne školske godine planira nastava za jednu grupu specijalnosti, dok se naredne javlja potreba za planiranjem nastave za neke druge specijalnosti, količina podataka koja se javlja može da prevaziđe mogućnosti nekih skromnijih alata, kao što je Microsoft Access. Na kraju, generisanje baze podataka efikasno je realizovano zbog mogućnosti automatskog kreiranja tabela u SQL Serveru iz modela podataka napravljenog u Erwinu.

Pošto je generisana baza podataka, za izradu korisničkog interfejsa izabran je Microsoft Access 2000, a pristupilo se i izradi Data Projecta ${ }^{1}$ koji će se koristiti za manipulaciju podacima, kao i za prikazivanje izveštaja. Odmah nakon završetka ove faze projekta počeo je unos test-podataka i popunjavanje šifarnika.

Implementacija logike sistema većim delom je realizovana na samom serveru baze podataka, izradom uskladištenih procedura i funkcija, a manji deo je implementiran $V B A^{2}$ kodom ugrađenim $\mathrm{u}$ korisnički interfejs. Korisnička aplikacija serveru baze podataka šalje zahtev za određenim podacima, server vrši obradu podataka iz baze i korisniku šalje rezultate te obrade. Na taj način optimizovan je i ubrzan rad čitavog sistema kroz bitno smanjenje količine podataka koji se prenose kroz mrežu.

\footnotetext{
${ }^{1}$ Projekat sačinjen u Microsoft Accessu koji manipuliše već postojećim podacima generisanim u nekom drugom SUBP. ${ }_{2}$ Visual Basic for Applications - programski jezik koji se koristi u alatima paketa Micosoft Office.
} 


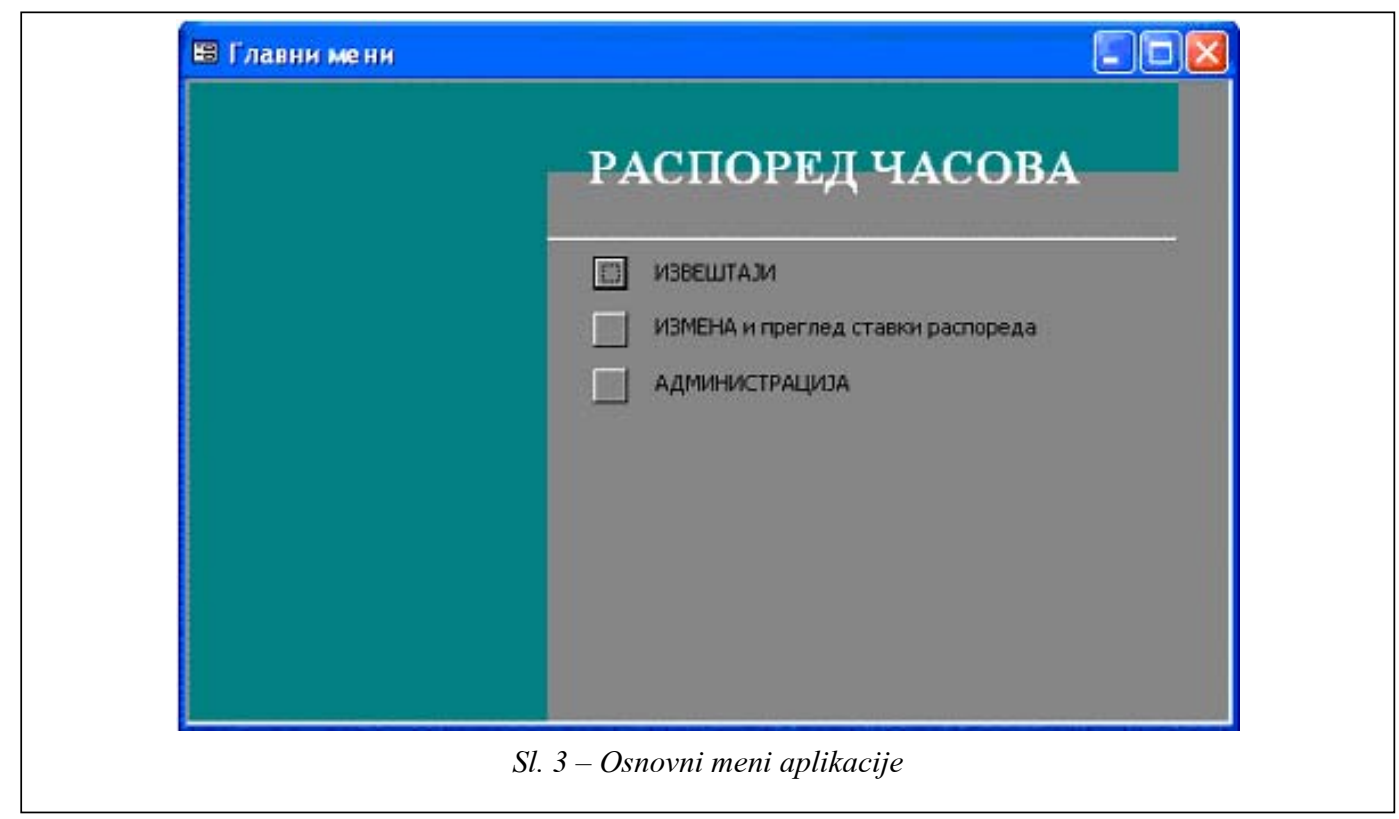

Prikaz implementiranog rešenja

Pri pokretanju aplikacije vrši se prijavljivanje korisnika za rad, pri čemu mu se dodeljuje jedan od četiri definisana nivoa prava pristupa podaci- ma. Nakon uspešnog prijavljivanja pojavljuje se osnovna forma aplikacije sa spiskom dostupnih akcija koje korisnik može da izvrši i podmenija kojima se može pristupiti u skladu sa definisanim pravima pristupa.

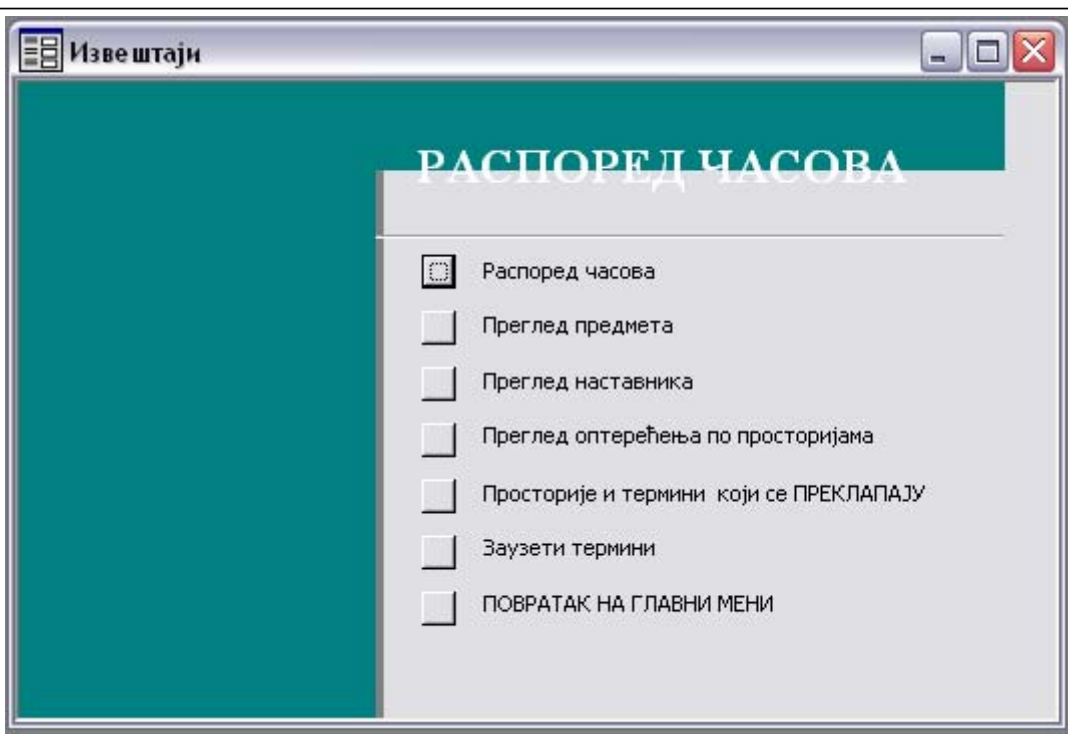

Sl. 4 - Meni izveštaji 


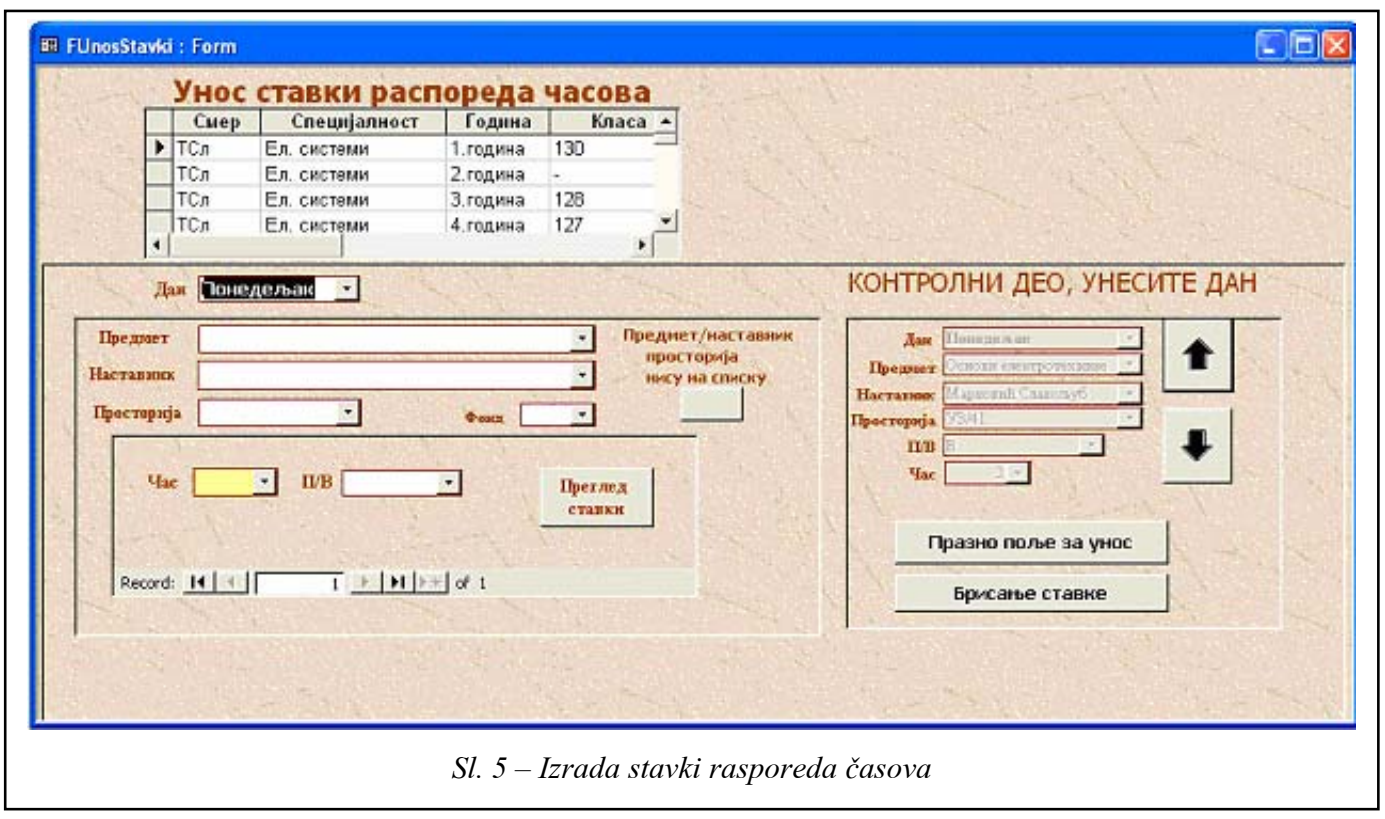

Korisnički interfejs (slika 3) veoma je jednostavan i intuitivan, pa njegova upotreba ne zahteva posebnu obuku korisnika.

Ključne stavke menija su Izveštaji i Izmena i pregled stavki rasporeda preko kojih se direktno pristupa rasporedu za određeni obrazovni profil, odnosno formi za ažuriranje, pregled i unošenje podataka relevantnih za raspored određenog profila (slika 4). Ovakav pristup je usvojen zbog činjenice da se raspored izradi jedanput, a zatim mnogo puta menja. Zbog ove činjenice pristup formi za inicijalno pravljenje rasporeda smešten je $\mathrm{u}$ Administraciji, dok je pristup formi za izmenu i pregled stavljen na glavni meni. Takođe, na glavnom meniju je i pristup rasporedima, jer se tako na najbrži način kontrolišu izmene koje su obavljene preko pomenute forme.

Inicijalna izrada jedne stavke za raspored časova, vrši se izborom opcije $A d$ ministracija, a zatim Unos stavki rasporeda. Tada se otvori forma UnosStavki (slika 5) preko koje se unose svi relevantni podaci izborom neke od ponuđenih vrednosti iz padajućih lista (smer, klasa, specijalnost, nastavnik, prostorija, predmet, čas, tip časa i dan). Mogućnost pogrešnog unosa podataka je maksimalno smanjena upotrebom padajućih lista. Podaci kojima se popunjava svaka od ovih lista direktno zavise od svih prethodno unetih podataka na formi. U listi Nastavnik nalaziće se samo oni nastavnici koji realizuju izabrani predmet. Slika 5 prikazuje formu za unos podataka o jednom terminu Rasporeda časova. Takođe, na ovoj formi postoji i kontrolni deo koji omogućava korisniku sekvencijalan pregled već unetih časova, tako da je time, pored izveštaja, obezbeđen još jedan način kontrole ispravnosti unosa stavki rasporeda.

Izgled gotovog rasporeda za jednu nastavnu grupu prikazan je na slici 6 . U prikazu se jednoznačno navodi termin (dan, čas), naziv predmeta, nastavnik, mesto iz- 


\begin{tabular}{|c|c|c|c|c|}
\hline & CMEP: MT C & 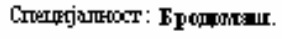 & Годан: Атфрна & Класа: 127 \\
\hline & Ilaremersax & ytgan & Cyema & Ye \\
\hline$\underset{0 \leqslant 30-1000}{1}$ & 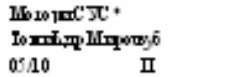 & 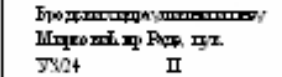 & 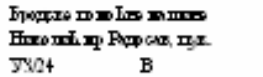 & 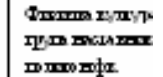 \\
\hline $\begin{array}{c}2 \\
0 \leqslant 30-10: 00\end{array}$ & 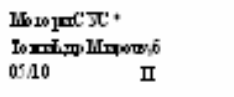 & 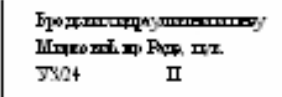 & 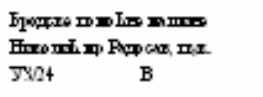 & 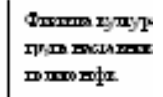 \\
\hline $\begin{array}{c}3 \\
\text { 10. } 20-21: 05\end{array}$ & 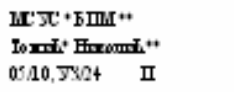 & 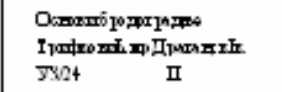 & 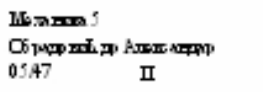 & 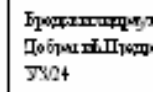 \\
\hline$\underset{11: 10-21: 55}{4}$ & 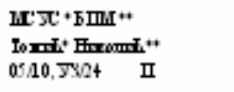 & 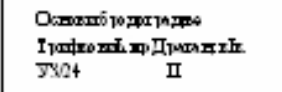 & 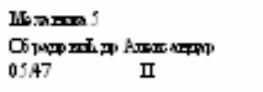 & 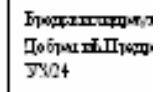 \\
\hline $\begin{array}{c}5 \\
1210-23: 40\end{array}$ & 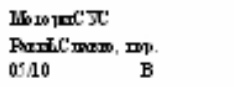 & 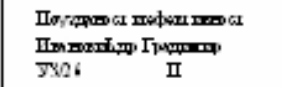 & 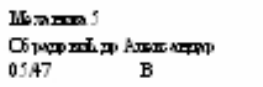 & \\
\hline $\begin{array}{c}6 \\
1210-13: 40\end{array}$ & 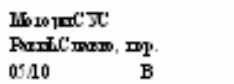 & 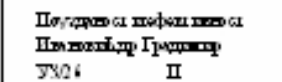 & 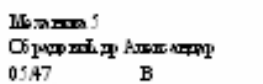 & \\
\hline $\begin{array}{c}7 \\
13.50-24: 35\end{array}$ & 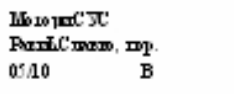 & 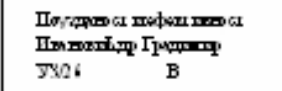 & & \\
\hline 8 & & & & \\
\hline \multicolumn{5}{|c|}{ Sl. 6-Prikaz dela rasporeda časova } \\
\hline
\end{tabular}

vođenja i tip časa. U slučaju da se neki predmet izvodi u neparnoj ili parnoj sedmici semestra, internim dogovorom takav predmet je označen jednom (neparna sedmica) ili sa dve (parna sedmica) zvezdice.

Aplikacija na jednostavan način prikazuje greške koje se mogu javiti pri planiranju rasporeda. Jedna od najčešćih može da bude da se $u$ istom terminu isplaniraju predavanja ili vežbe dva različita predmeta (slika 7). U tom slučaju, kao što je prikazano na slici 7 , jednostavno treba obrisati jedan od predmeta (u prikazanom slučaju Mehaniku 5, sreda 2. čas).

Interesantno je da je ova osobina aplikacije iskorišćena u Srednjoj zanatskoj školi, koja je usled malog broja đaka i fonda za teorijsku nastavu specifična po tome da jedno odeljenje ima više specijalnosti, i koje imaju neke zajedničke predmete, a neke slušaju odvojeno (slika 8).

U prikazanom primeru zajednički predmeti su matematika, srpski jezik i uređenje društva, dok su predmeti koje grupe đaka unutar odeljenja slušaju odvojeno tehnologija rada, poznavanje materijala i zaštitni premazi.

Osim ove greške, aplikacija zahvaljujući izveštaju Pregled nastavnika po danima i predmetima koje predaju može da otkrije i slučaj kada je nastavniku isplanirano dva ili više predavanja $u$ istom terminu. Pored ove kontrolne uloge u Organu za planiranje nastave, ovaj izveštaj 


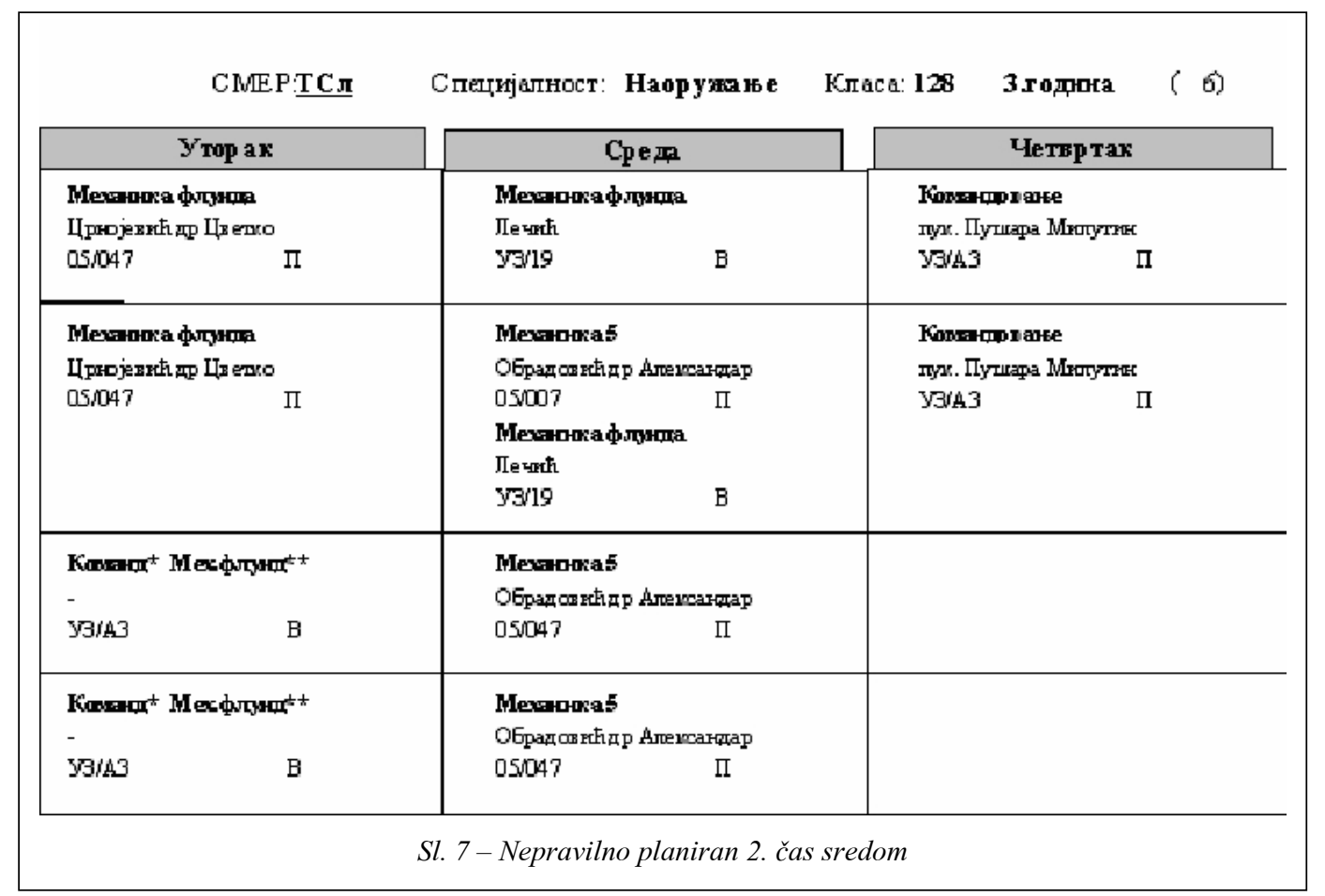

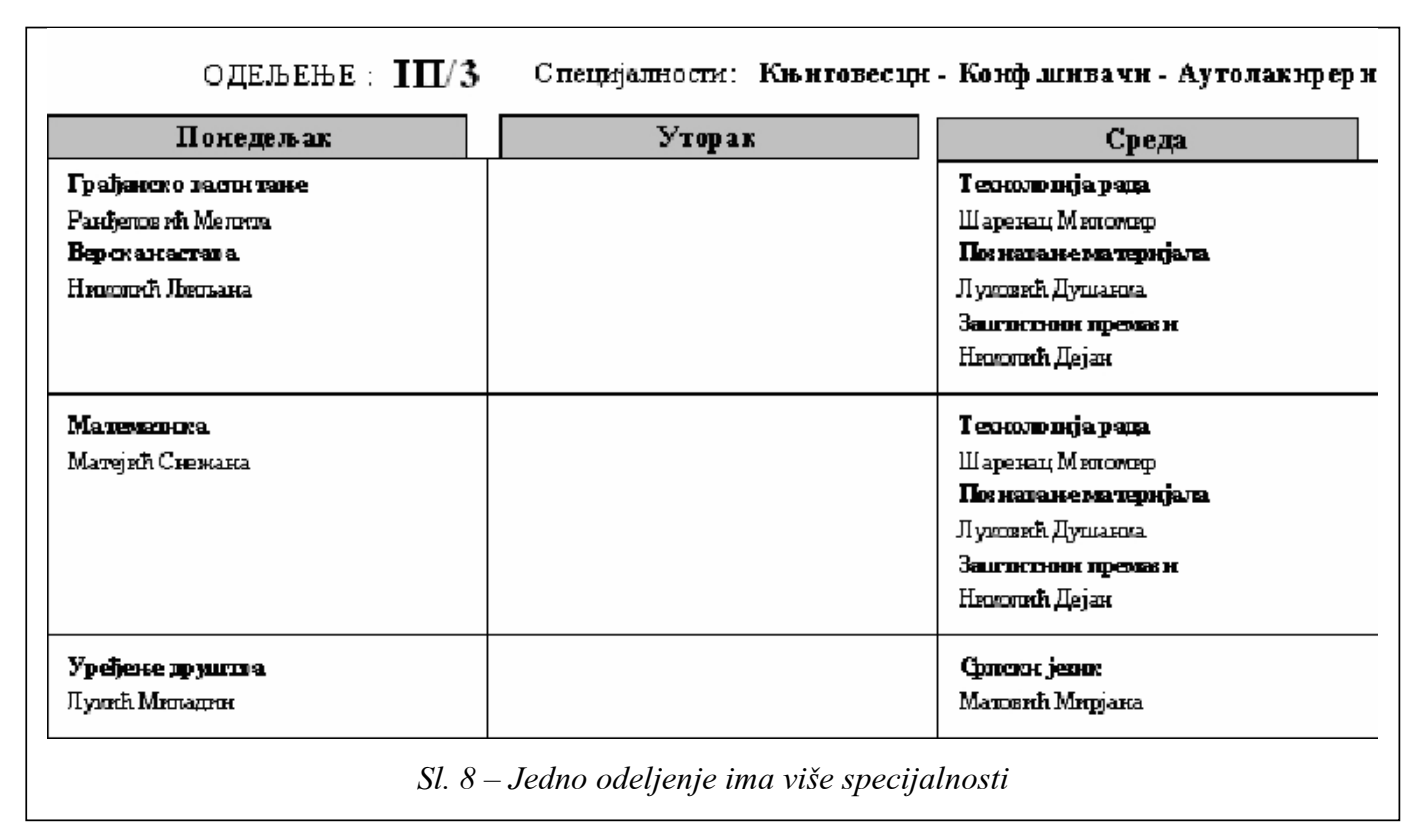

se distribuira nastavnom osoblju kao nastavnički raspored časova, odnosno plan angažovanja nastavnika u semestru.
Aplikacija poseduje i izveštaj Raspored po danima koji služi kao kontrolni izveštaj i omogućava brzo i efikasno 
utvrđivanje ko, gde i koji predmet drži u određenom terminu (slika 9).

\section{Zaključak}

U radu je predstavljeno softversko rešenje za podršku planiranju nastave $u$ visokoškolskim i ostalim obrazovnim ustanovama. Rešenje je realizovano radi automatizacije u izradi plana, kreiranju izveštaja prema korisnicima (smerovima, nastavnim grupama, studentima, nastavnicima, fakultetima - spoljnim saradnicima, itd.) i automatskoj proveri ispravnosti unetih podataka. Koncepcija rešenja omogućava rad u mrežnom okruženju i unos i čuvanje podataka rasporeda za sve obrazovne profile na jednom mestu.

Za implementaciju rešenja odabrane su Microsoftove tehnologije kao najrasprotranjenije i opšteprihvaćene u Vojsci Srbije i Crne Gore. Kao sistem za upravljanje bazom podataka iskorišćen je Microsoft SQL Server 2000, a za izradu korisničkog interfejsa Microsoft Access 2000. Ovakvo opredeljenje omogućava upotrebu aplikacije u svim organizacionim celinama Odseka logistike Vojne akademije i ustanovama koje se bave visokoškolskim obrazovanjem, bez ili uz vrlo male izmene postojeće hardverske i softverske infrastrukture. Bitan opredeljujući faktor jeste i navika $\mathrm{i}$ iskustvo budućih korisnika u radu sa Microsoft-ovim tehnologijama.

Aplikacija je za sada instalirana u nastavnom organu Odseka logistike Vojne akademije. Posle završene test-faze i otklanjanja uočenih nedostataka počelo je njeno aktivno korišćenje u izradi rasporeda časova za zimski semestar školske $2005 / 2006$. godine. Iskustva u radu su pozitivna. Vreme potrebno za izradu rasporeda je bitno skraćeno, a kvalitet izrađenih rasporeda je poboljšan automatskim otkrivanjem i lakim ispravljanjem uočenih grešaka u planiranju. Praćenje i realizacija nastave unapređeni su jednostavnom izra-

\begin{tabular}{|c|c|c|c|c|c|}
\hline & $\begin{array}{c}\text { 1.yac } \\
08: 15-09: 00\end{array}$ & $\begin{array}{c}\text { 2.yac } \\
\text { 09:05 - 09:50 }\end{array}$ & $\begin{array}{c}\text { 3.чac } \\
09: 05 \text { - 09:50 }\end{array}$ & $\begin{array}{c}\text { 4.yac } \\
\text { 09:05-09:50 }\end{array}$ & $\begin{array}{c}\text { 5.чac } \\
\text { 09:05-09:50 }\end{array}$ \\
\hline \multicolumn{6}{|c|}{ Понедељак } \\
\hline \multicolumn{6}{|l|}{$\mathrm{TC} \pi$} \\
\hline \multicolumn{6}{|l|}{129} \\
\hline \multirow{2}{*}{ Motongr exm. } & Meratrara 3 & 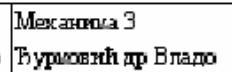 & $\begin{array}{l}\text { Механкана } 3 \\
\text { Ћуриовић дт Втадо }\end{array}$ & & 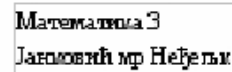 \\
\hline & 8320 & $y 320$ & 3320 & & Y3/42 \\
\hline \multirow{2}{*}{ Pavet. скет. } & 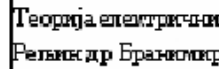 & 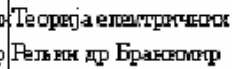 & 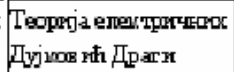 & 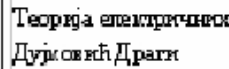 & 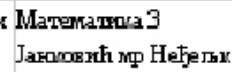 \\
\hline & YA2 & ysin2 & $53 / 22$ & $y 3 / 42$ & Y3/Al \\
\hline \multirow{2}{*}{ УEC } & Ormima xenria & Orerta xemaja & Oтшта келита & Omand xesraia & 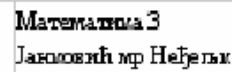 \\
\hline & bs,002 & 05,002 & 05,002 & 05002 & YS/A1 \\
\hline
\end{tabular}


dom izveštaja koji se blagovremeno dostavljaju svim pretpostavljenim i potčinjenim organizacionim celinama i fakultetima Beogradskog univerziteta.

Uz stalnu saradnju sa korisnicima, proces unapređenja funkcionalnosti i korisničkog interfejsa realizuje se neprekidno. Planira se proširenje informacionog sistema uključivanjem podataka o ispitima, i njegova integracija u jedinstveni Automatizovani informacioni sistem.

Zahvaljujući univerzalno projektovanom modelu podataka, implementira- no rešenje se, uz minimalne izmene, može primeniti u bilo kojoj visokoškolskoj ustanovi unutar i van Vojske Srbije i Crne Gore, a već se primenjuje u Srednjoj zanatskoj školi u Beogradu.

Literatura:

[1] Gunderloy M.: SQL Server 2000, Mikro knjiga, Beograd, 2001 [2] Grupa autora: Majstor za Access 2002 VBA, Kompjuter biblioteka, Cačak, 2001.

[3] Tot, I.: Access 2000 - Skripta, Beograd, 2001.

[4] Sceppa, D.: Programming ADO, Microsoft Press, Redmond, 2000.

[5] Nastavni planovi i programi Odseka logistike, Vojna akademija, Beograd, 1997. 


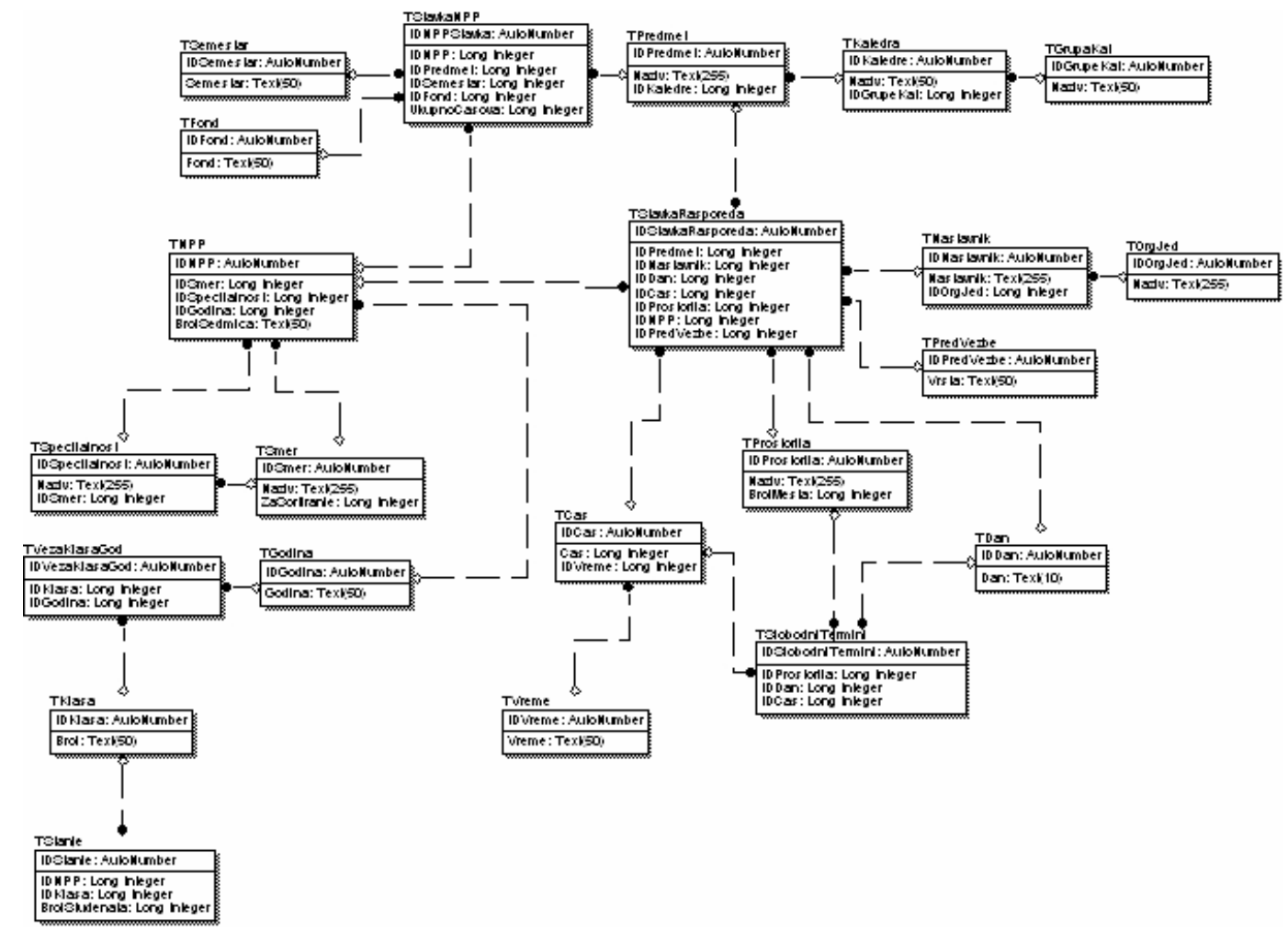

Sl. 1 - Logistički model podataka 


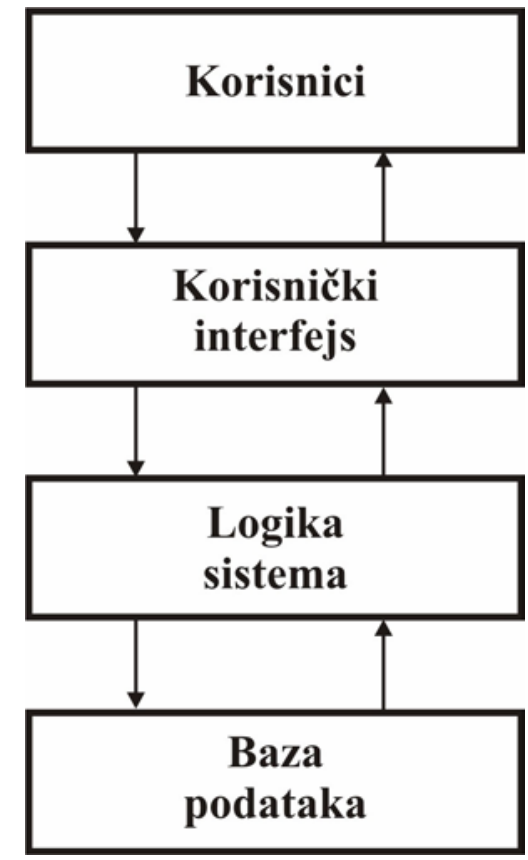

Sl. 2 - Troslojna arhitektura sistema 


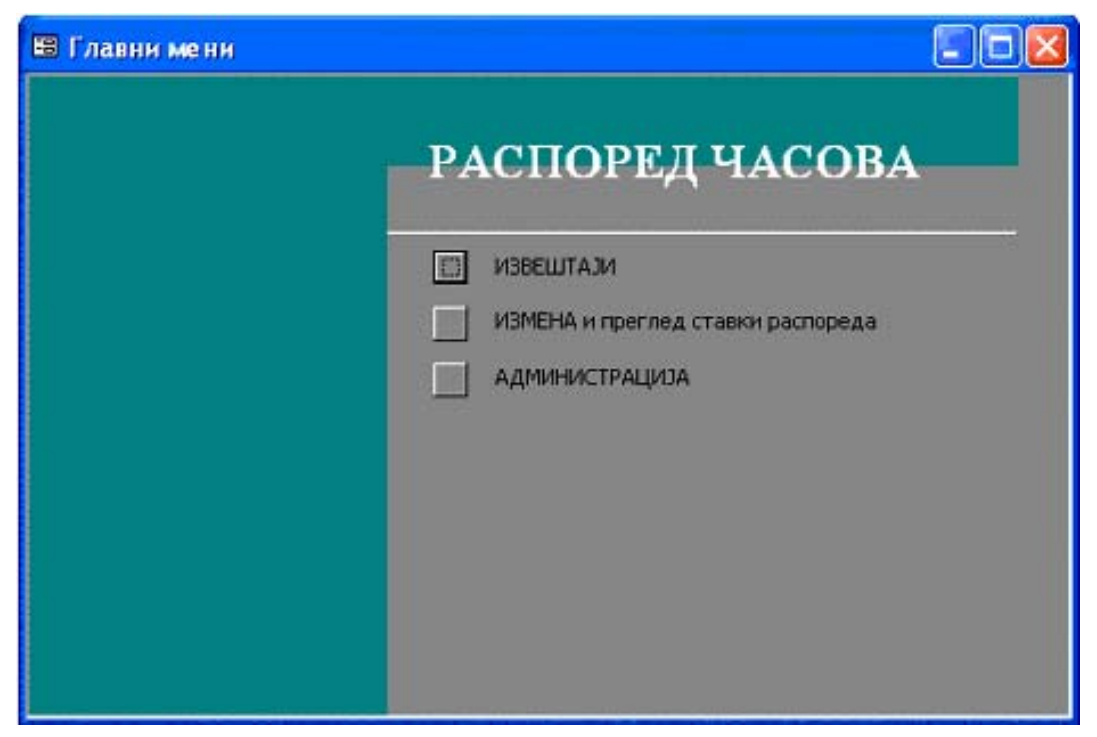

Sl. 3 - Osnovni meni aplikacije

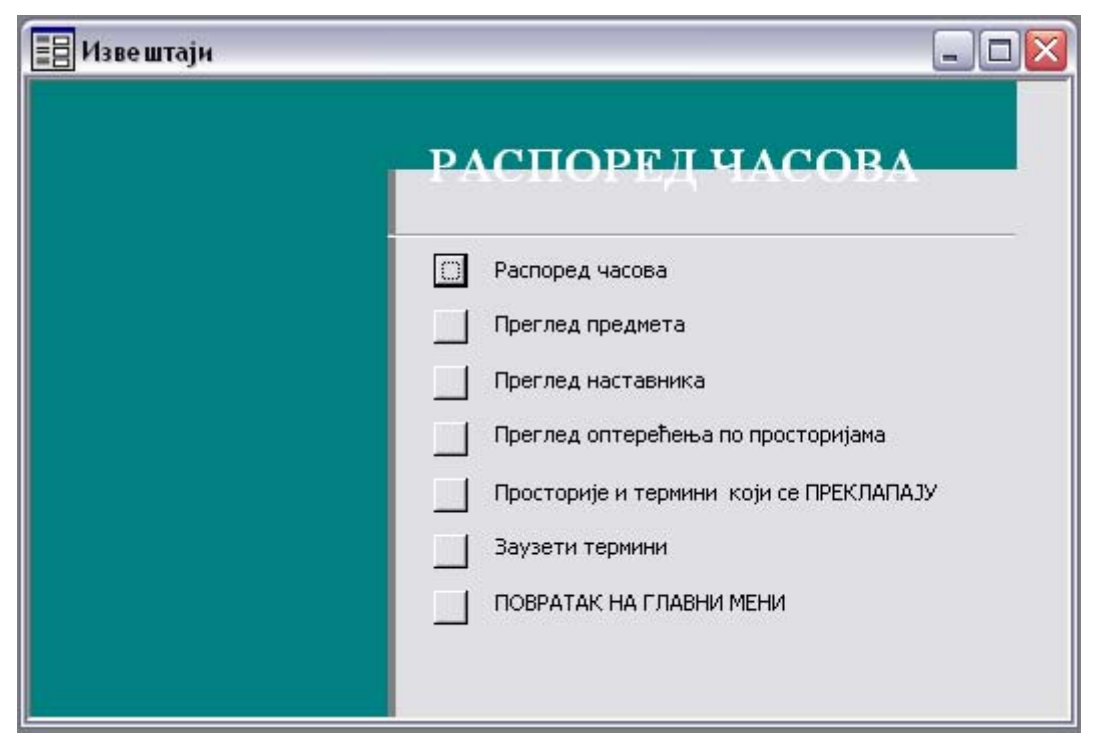

Sl. 4 - Meni izveštaji 


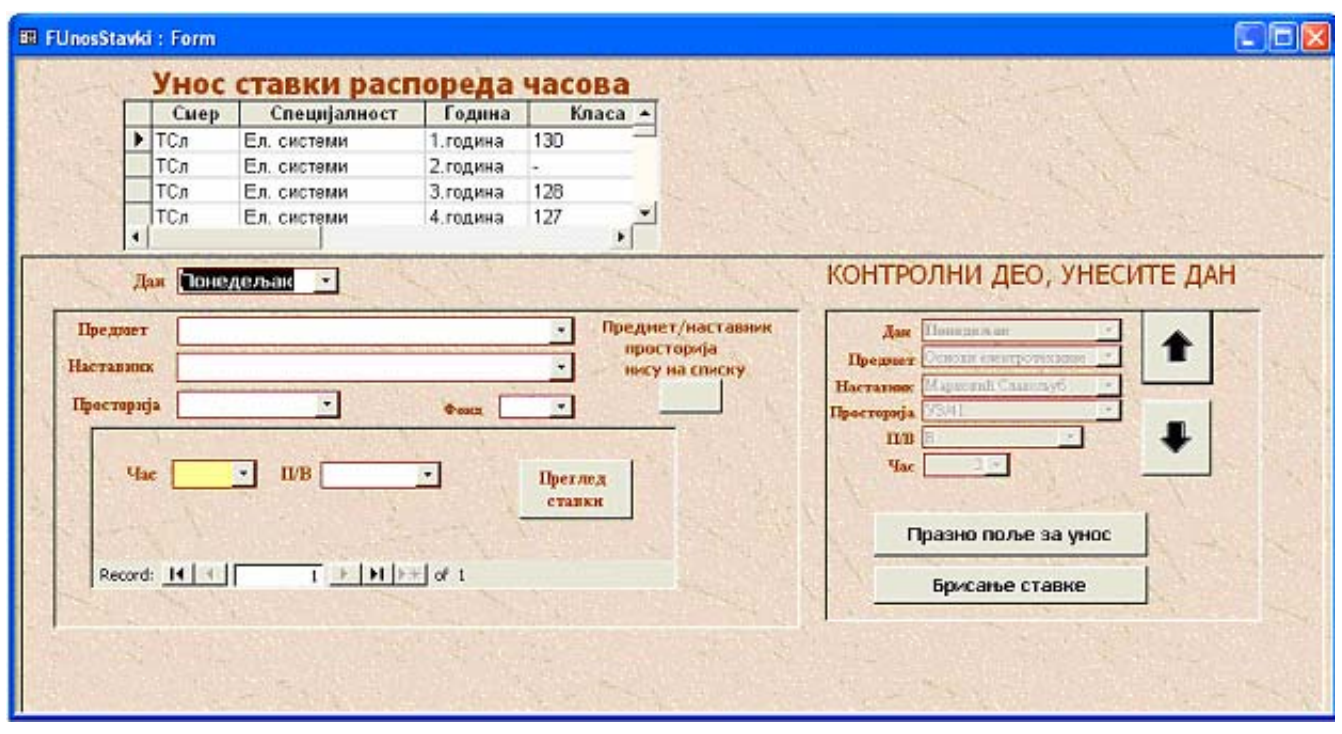

Sl. 5 - Izrada stavki rasporeda časova 


\begin{tabular}{|c|c|c|c|c|}
\hline & CMEP: MT CS & 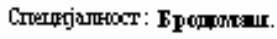 & Годана: 4тфнка & Kanca: 127 \\
\hline & II aremel ax & Yrgax & Cyema & $\underline{Y}$ \\
\hline $\mathbf{1}$ & 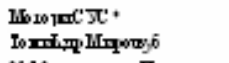 & 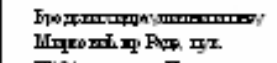 & 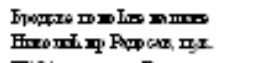 & 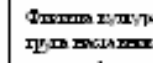 \\
\hline $0 \mathrm{Q} 30-20: 00$ & $05 / 0$ & TY24 & गN24 & 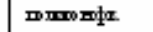 \\
\hline $\begin{array}{c}2 \\
0030-20: 00\end{array}$ & 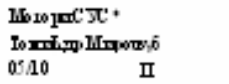 & 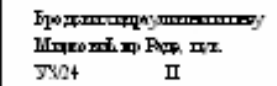 & 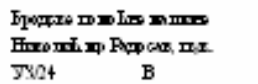 & 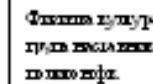 \\
\hline $\begin{array}{c}3 \\
10.20-21: 05\end{array}$ & 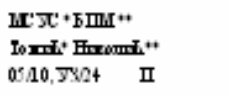 & 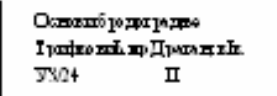 & 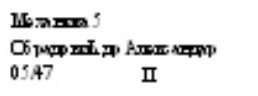 & 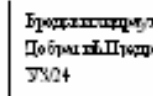 \\
\hline$\frac{4}{11 \cdot 10-21: 55}$ & 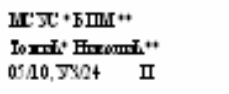 & 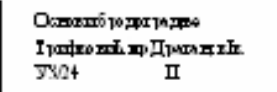 & 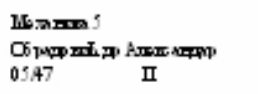 & 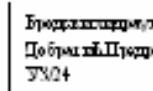 \\
\hline $\begin{array}{c}5 \\
1210-23: 40\end{array}$ & 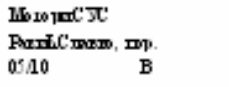 & 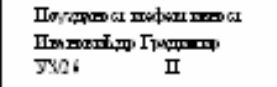 & 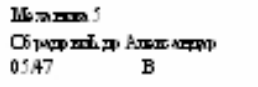 & \\
\hline$\underset{1210-23: 40}{6}$ & 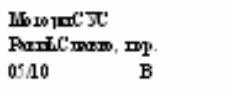 & 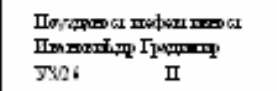 & 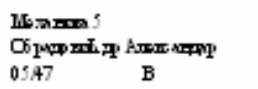 & \\
\hline $\begin{array}{c}7 \\
13.50-24: 35\end{array}$ & 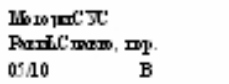 & 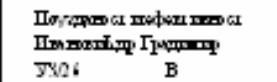 & & \\
\hline 8 & & & & \\
\hline
\end{tabular}

Sl. 6- Prikaz dela rasporeda časova 


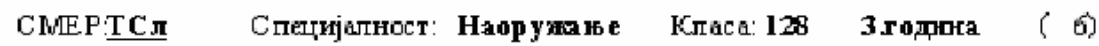

\begin{tabular}{|c|c|c|}
\hline$Y_{\text {Top ax }}$ & Cpeдp & Yeтreptax \\
\hline 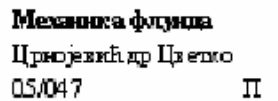 & 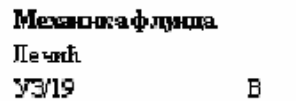 & 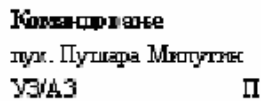 \\
\hline 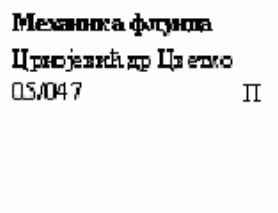 & 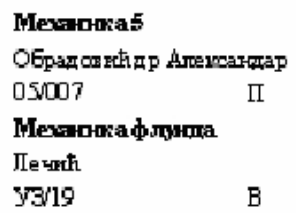 & 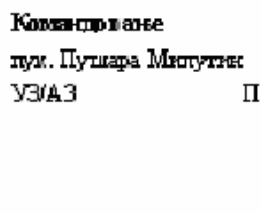 \\
\hline 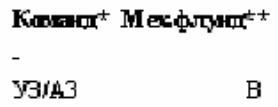 & 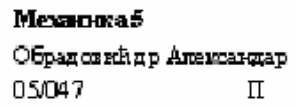 & \\
\hline 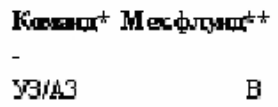 & 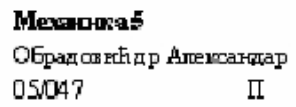 & \\
\hline
\end{tabular}

Sl. 7 - Nepravilno planiran 2. čas sredom

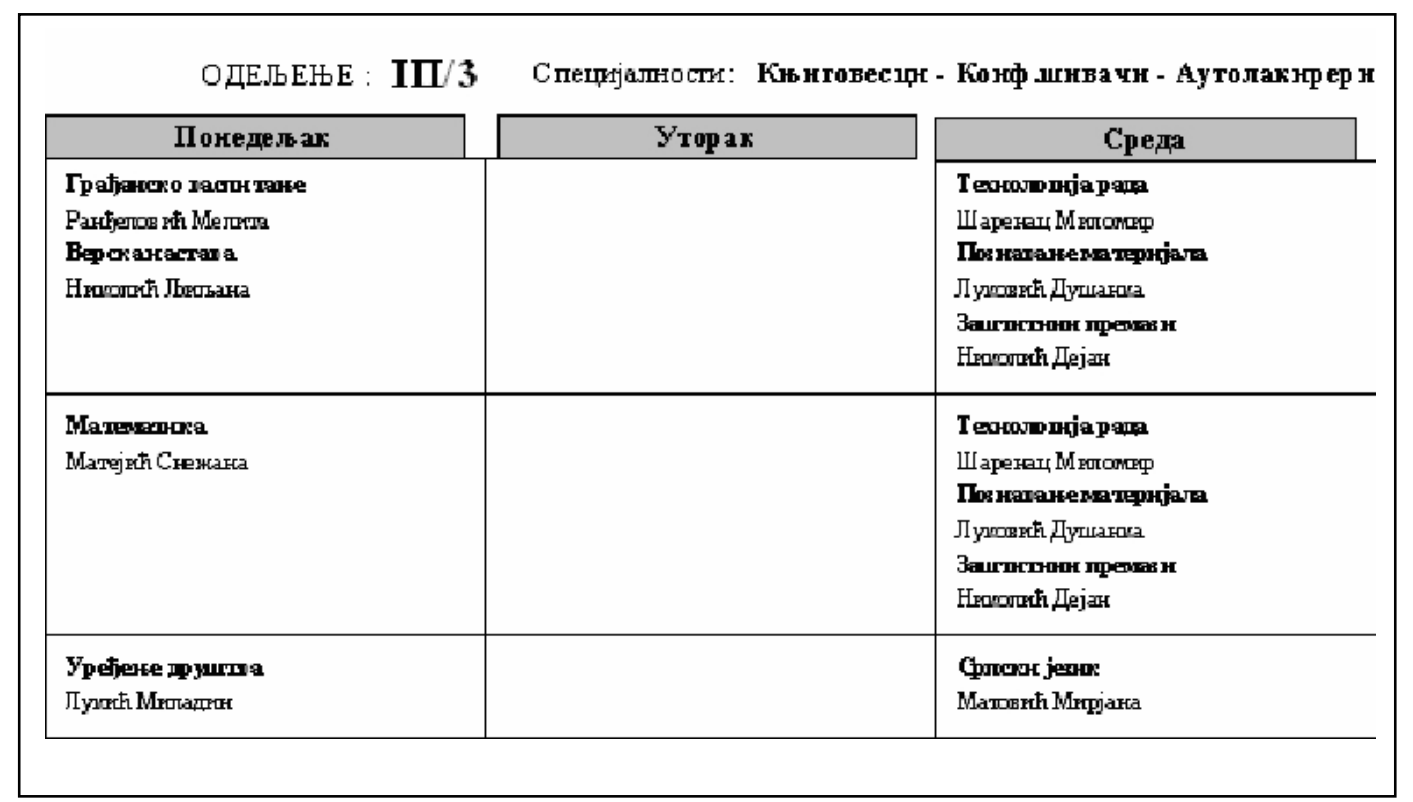

Sl. 8 - Jedno odeljenje ima više specijalnosti 


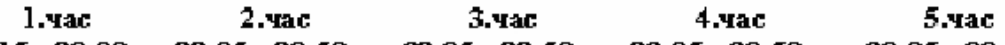

08:15-09:00 09:05-09:50 09:05-09:50 09:05-09:50 09:05-09:50

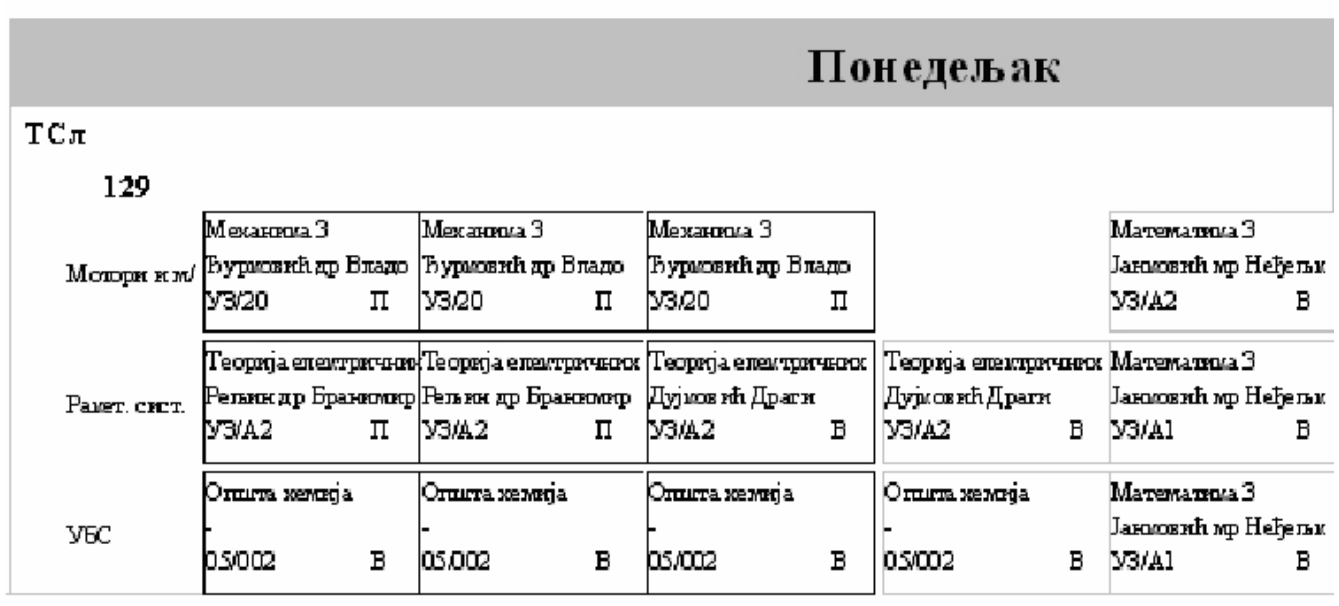

Sl. 9 - Isečak rasporeda časova po danima 
